\title{
SISTEM PENUNJANG KEPUTUSAN PENENTUAN SUPPLIER PERANGKAT SOSIALISASI TERBAIK PADA KEDEPUTIAN BIDANG PENGAWASAN INTERNAL DAN PENGADUAN MASYARAKAT KOMISI PEMBERANTASAN KORUPSI DENGAN METODE SIMPLE ADDITIVE WEIGHTING (SAW)
}

\author{
Widiastutik $^{1)}$, Yudi Santoso ${ }^{2)}$ \\ ${ }^{1}$ Sistem Informasi, Fakultas Teknologi Informasi, Universitas Budi Luhur \\ ${ }^{1,2} \mathrm{Jl}$. Raya Ciledug, Petukangan Utara, Kebayoran Lama, Jakarta Selatan 12260 \\ E-mail : 1612510600@student.budiluhur.ac.id ${ }^{1)}$, yudi.santoso@budiluhur.ac.id ${ }^{2)}$
}

\begin{abstract}
Abstrak
Dalam pengadaan barang sering dihadapkan pada masalah pemilihan supplier yang benar-benar dapat diandalkan perusahaan. Beberapa faktor yang mendorong kelancaran proses pengadaan antara lain yaitu keberadaan supplier. Hal ini berkaitan dengan fungsi supplier sebagai pemasok barang yang seringkali tidak sesuai dengan apa yang dibutuhkan oleh perusahaan karena keterlambatan waktu pengiriman, kualitas barang yang dikirim tidak sesuai permintaan dan tidak menutup kemungkinan supplier tidak dapat menyediakan barang yang diminta oleh perusahaan. Ini membuat perusahaan harus pandai memilih supplier yang tepat. Kedeputian Bidang Pengawasan Internal dan Pengaduan Masyarakat di Komisi Pemberantasan Korupsi, bertugas memberikan sosialisasi kepada Kementerian/Lembaga maupun masyarakat luas mengenai prosedur pelaporan pengaduan korupsi yang terjadi disekitar. Untuk mendukung kegiatan ini, perlu diadakan perangkat sosialisasi yang nantinya akan digunakan untuk memberikan apresiasi kepada pelapor, dan kegiatan lainnya. Untuk memfasilitasi Kedeputian Bidang Pengawasan Internal dan Pengaduan Masyarakat dalam menentukan supplier yang sesuai dengan kriteria yang diinginkan, diperlukan sistem atau metode yang tidak hanya memprioritaskan subjektivitas tetapi menggunakan data sebagai referensi dalam memilih supplier, sehingga hasilnya bisa lebih efektif dan akurat. Untuk itu dibuatlah sebuah sistem penunjang keputusan dengan menggunakan perhitungan metode SAW yang bertujuan untuk mempermudah dan memberikan pilihan supplier yang tepat dan juga membantu mengatasi masalah yang ada dalam pengambilan keputusan.
\end{abstract}

Kata kunci: Supplier Terbaik, Metode SAW, Sistem Penunjang Keputusan, Perangkat Sosialisasi.

\section{PENDAHULUAN}

Pemilihan supplier yang tepat diperlukan dalam menyediakan kebutuhan perangkat sosialisasi. Keputusan untuk memilih supplier bukanlah hal yang mudah, pada kenyataannya banyak hal yang harus diperhatikan dalam memilih supplier yang tepat. Harga secara umum adalah satu-satunya hal yang dipertimbangkan dalam pemilihan supplier, tetapi sebenarnya ada beberapa kriteria yang harus dipertimbangkan dalam memilih supplier, yaitu kualitas, ketepatan waktu pengiriman, dan layanan. Namun terkadang kriteria ini bertentangan satu sama lain. Misalnya, supplier lebih suka menawarkan harga rendah dengan kualitas barang di bawah ratarata, sementara supplier lain menawarkan barang dengan kualitas baik tetapi waktu pengirimannya tidak pasti.

Dari penjelasan diatas, Permasalahan yang penulis temukan dalam pemilihan supplier untuk pengadaan perangkat sosialisasi pada Kedeputian Bidang PIPM antara lain:

a. Tidak adanya supplier terbaik yang ditentukan pada Kedeputian Bidang PIPM yang menyebabkan keraguan dalam mengambil keputusan.

b. Sistem evaluasi dan seleksi supplier sebelumnya hanya menekankan aspek/kriteria biaya dan ditambah penilaian lain yang sifatnya subyektif.

Untuk mempermudah memilih supplier, diperlukan suatu sistem atau metode yang tidak hanya memprioritaskan subjektivitas, tetapi juga menggunakan data sebagai referensi dalam memilih supplier yang tepat, sehingga hasilnya bisa lebih efektif dan akurat. Untuk itu dibuatlah sebuah sistem penunjang keputusan dengan menggunakan metode perhitungan Simple Additive Weighting (SAW) yang bertujuan untuk memfasilitasi dan memberikan pilihan supplier yang tepat sesuai dengan kriteria dan diharapkan juga membantu mengatasi masalah yang ada dalam pengambilan sebuah keputusan..

Manfaat dari penelitian ini adalah dengan adanya sistem penunjang keputusan dalam pemilihan supplier akan membantu Pejabat Pembuat Komitmen di Kedeputian Bidang PIPM dalam melakukan pengambilan keputusan pemilihan supplier yang tepat sesuai dengan kriteria yang telah 
ditentukan serta dapat mengurangi tingkat kesalahan dalam pengambilan suatu keputusan dan diharapkan dengan adanya penelitian ini dapat menjadi referensi dan motivasi dalam pengembangan suatu sistem penunjang keputusan pemilihan supplier bagi peneliti selanjutnya yang memiliki permasalahan yang sama atau masalah lain dengan metode yang sama.

Menurut [1] mengungkapkan bahwa pengertian sistem informasi adalah "Suatu sistem di dalam suatu organisasi yang mempertemukan kebutuhan pengolahan transaksi harian yang mendukung fungsi operasi organisasi yang bersifat manajerial dengan kegiatan strategi dari suatu organisasi untuk dapat menyediakan kepada pihak luar tertentu dengan laporan-laporan yang diperlukan”.

Pengertian Sistem Penunjang Keputusan (SPK) adalah: “Aplikasi interaktif berbasis komputer yang mengkombinasikan data dan model matematis untuk membantu proses pengambilan keputusan dalam menangani suatu masalah” [2].

Menurut [2] menyebutkan bahwa ada tiga aspek utama dalam SPK yaitu:

a. Data, data yang digunakan dalam SPK adalah data yang diambil dari data warehouse pada organisasi yang telah dikategorikan berdasarkan kebutuhan.

b. Model matematis, merupakan bagian untuk menganalilis data dan berfungsi untuk merubah data menjadi informasi dan knowledge yang berguna untuk pengambilan keputusan.

c. Antarmuka pengguna (user interface). Aspek ini merupakan aspek yang secara langsung dilihat dan berinteraksi dengan end user atau dalam hal ini pemegang keputusan. Data yang ditampilkan harus memberikan informasi yang valid, reliable dan dapat mendukung untuk pengambilan keputusan.

Aspek Utama dalam SPK disajikan pada Gambar 1.

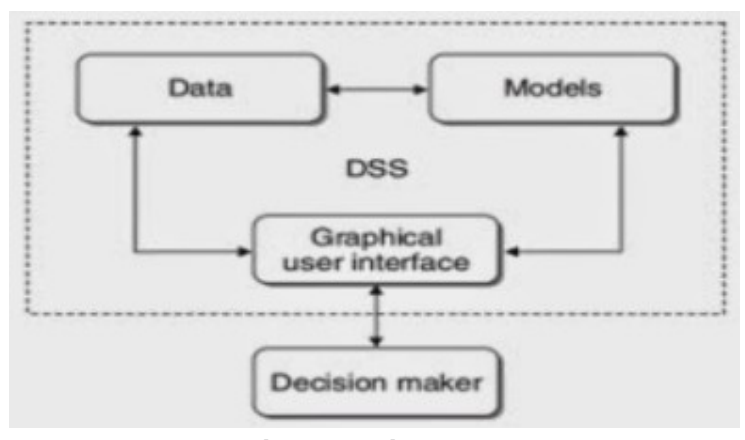

Gambar 1. Aspek Utama SPK

Metode SAW sering juga dikenal dengan istilah metode penjumlahan terbobot. Konsep dasar metode
SAW adalah "Mencari penjumlahan terbobot dari rating kinerja pada setiap alternatif pada semua atribut” [3].

Seleksi supplier adalah salah satu masalah terpenting perusahaan yang harus dipertimbangkan secara sistematis dari sudut pandang pembuat keputusan. Perusahaan yang memutuskan untuk membeli bahan alih-alih membuatnya harus memilih supplier. Dalam prosesnya, pemilihan supplier mempertimbangkan beberapa faktor, seperti persediaan dan biaya transportasi, ketersediaan pasokan, kinerja pengiriman, dan kualitas supplier.

Pemilihan supplier didefinisikan sebagai proses menemukan supplier yang mampu menyediakan pembeli dengan hak untuk produk atau layanan berkualitas dengan harga yang tepat, jumlah yang tepat dan pada waktu yang tepat. Pemilihan supplier untuk kemitraan mungkin merupakan langkah terpenting yang mempengaruhi akhir pembelipemasok. Jika proses ini dilakukan dengan benar, kualitas yang lebih tinggi, hubungan yang lebih tahan lama lebih dapat dicapai.

Penelitian tentang sistem penunjang keputusan pemilihan supplier pernah dilakukan oleh [4]. Metode yang digunakan adalah AHP dan SAW. Tujuan dari penelitian ini adalah membuat sebuah aplikasi yang dapat membantu mempermudah dalam proses pemilihan supplier dan dengan menggunakan metode AHP dan SAW ini dapat membantu dalam melakukan penilaian sehingga tidak lagi diukur sebatas pendapat dan perasaan saja. Dalam sistem penunjang keputusan ini terdapat master data supplier, sehingga dapat membantu pegawai dalam mencari data supplier. Dengan adanya laporan hasil pemilihan supplier, Decision maker mudah untuk membandingkan hasil kinerja supplier.

Penelitian tentang sistem penunjang keputusan pemilihan supplier pernah juga dilakukan oleh [5]. Metode yang digunakan adalah SAW dan WP. Tujuan dari penelitian ini adalah membuat sebuat sistem penunjang keputusan yang ditujukan kepada departemen purchasing, departemen produksi, dan departemen (Quality Control). Beberapa metode yang digunakan dalam membantu proses penyeleksian atau pemilihan karyawan terbaik adalah metode Weighted Product (WP) dan metode Simple Additive Weighting (SAW). Kedua metode ini adalah metode penyelesaian pada masalah MADM (Multi Attribute Decision Making).

\section{METODE PENELITIAN}

\subsection{Metode Pengumpulan Data}

Untuk menyelesaikan masalah yang ada di Kedeputian Bidang PIPM, penelitian menggunakan pendekatan model Sistem Pendukung Keputusan (SPK), penulis menggunakan beberapa metode 
pengumpulan data dengan memperoleh informasi dari sistem saat ini, yaitu:

\section{a. Observasi}

Pada tahap pengamatan ini, penulis mengumpulkan data dengan melakukan pengamatan langsung di Sekretariat Deputi Bidang PIPM untuk mendapatkan gambaran yang jelas tentang bagaimana proses pemilihan supplier telah berlangsung sejauh ini.

b. Wawancara

Untuk mendapatkan informasi dan data lainnya, penulis juga melakukan wawancara dengan Pejabat Pembuat Komitmen di Kedeputian Bidang PIPM. Pada tahap ini diperoleh data tentang profil perusahaan, visi-misi, struktur organisasi, dan menggambarkan tugas dan fungsinya. Kemudian kriteria dan bobot untuk pemilihan supplier juga diperoleh pada tahap ini.

c. Analisa Dokumen

Mencari informasi berdasarkan dokumen terkini yang terkait dengan dokumen data supplier, data kriteria, bobot, dan penawaran harga.

d. Studi Pustaka

Studi pustaka dilakukan untuk menemukan teori yang berkaitan dengan masalah yang dihadapi. Penulis mempelajari berbagai sumber seperti buku, jurnal, dan catatan selama kuliah. Termasuk studi pustaka melalui internet seperti perpustakaan digital, situs web, dan sumber daya lain yang ditemukan di internet.

Dari hasil studi pustaka yang dilakukan penulis mempelajari tentang langkah-langkah menyelesaikan permasalahan pemilihan supplier di Kedeputian Bidang PIPM dengan menggunakan metode SAW.

Langkah-langkah untuk menyelesaikan metode SAW adalah sebagai berikut:

1) Tentukan kriteria yang akan digunakan sebagai referensi dalam pengambilan keputusan.

2) Tentukan nilai bobot masing-masing kriteria yang telah diperoleh sebelumnya.

3) Tentukan peringkat kesesuaian setiap alternatif pada setiap kriteria.

4) Buat matriks keputusan berdasarkan kriteria, lalu normalkan matriks berdasarkan persamaan yang disesuaikan dengan jenis atribut (atribut laba atau atribut biaya) untuk mendapatkan matriks normalisasi R.

Berikut adalah rumus untuk mencari matriks yang dinormalisasi.

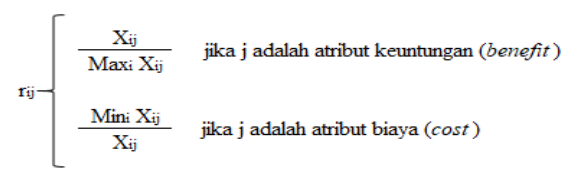

5) Berikan nilai presensi untuk setiap alternatif (Vi) dengan rumus:

$$
\mathrm{V}_{\mathrm{i}}=\sum_{\mathrm{j}=1}^{\mathrm{n}} \mathrm{w}_{\mathrm{j}} \mathrm{r}_{\mathrm{ij}}
$$

Keterangan:

$\mathrm{Vi}=$ ranking untuk setiap alternatif.

wj = nilai bobot setiap kriteria.

rij = nilai rating kinerja kriteria ternormalisasi.

Hasil akhir diperoleh dari proses perangkingan yaitu penjumlahan dari matriks perkalian dinormalisasi $\mathrm{R}$ dengan vektor bobot sehingga nilai terbesar dipilih sebagai alternatif terbaik (Ai) sebagai solusinya.

\subsection{Instrumentasi}

Dalam penelitian ini penulis menggunakan teknik wawancara sebagai instrumentasi. Wawancara dilakukan dengan Pejabat Pembuat Komitmen di Kedeputian Bidang PIPM sebagai pembuat keputusan dalam memilih supplier untuk mendapatkan informasi dalam proses penentuan supplier di Kedeputian bidang PIPM.

\section{HASIL DAN PEMBAHASAN}

\subsection{Teknis Analisis Data}

Analisis yang digunakan dalam penelitian ini adalah analisis deskriptif, yaitu dengan metode Simple Additive Weighting (SAW). Analisis deskriptif dilakukan melalui presentasi ringkasan hasil wawancara, sedangkan SAW sebagai instrumen untuk menentukan prioritas kebijakan dalam menentukan supplier di Kedeputian Bidang PIPM.

\subsection{Proses Bisnis Berjalan}

Pada saat awal, Admin Pengadaan Menerima Permintaan Pengadaan Perangkat Sosialisasi dari unit kerja di Kedeputian Bidang PIPM, Kemudian Admin pengadaan menghubungi supplier dengan menanyakan kesediaan supplier atas spesifikasi barang yang diminta, harga dan waktu pengiriman. Jika harga yang ditawarkan oleh supplier masih di bawah harga SBU yang ditetapkan maka dianggap berhak meneruskan evaluasi supplier, tetapi jika harga yang ditawarkan melebihi harga SBU maka supplier tersebut tidak berhak menjadi kandidat. Selanjutnya admin pengadaan akan menanyakan waktu pengiriman lalu membandingkannya dengan supplier lain, jika pengiriman bisa dilakukan dalam waktu 7 hari atau kurang dari 7 hari maka supplier tersebut berhak melanjutkan evaluasi tetapi jika tidak sanggup mengirimkan barang dalam 7 hari maka tidak dilanjutkan karena kebutuhan pengadaan yang harus segera dipenuhi. Selanjutnya admin pengadaan akan meminta sample kepada kandidat 
supplier dari produk yang mereka buat, admin pengadaan akan menilai kualitas barangnya dari spesifikasi, desain gambar dan warna, jika kualitas barang bagus supplier tersebut lanjut ke tahap penilaian, tetapi apabila kualitas barang tidak baik maka supplier tersebut tidak dapat diteruskan ke tahap penilaian.

Setelah mendata semua kandidat supplier yang lolos, admin pengadaan lalu melakukan penilaian terhadap semua kriteria pemilihan tersebut. Kemudian hasil dari penilaian tersebut diserahkan kepada Pejabat Pembuat Komitmen Deputi Bidang PIPM untuk dipilih yang akan menjadi supplier perangkat sosialisasi pada Kedeputian Bidang PIPM.

Proses bisnis berjalan pemilihan supplier perangkat sosialisasi dijelaskan dengan activity diagram pada Gambar 2.

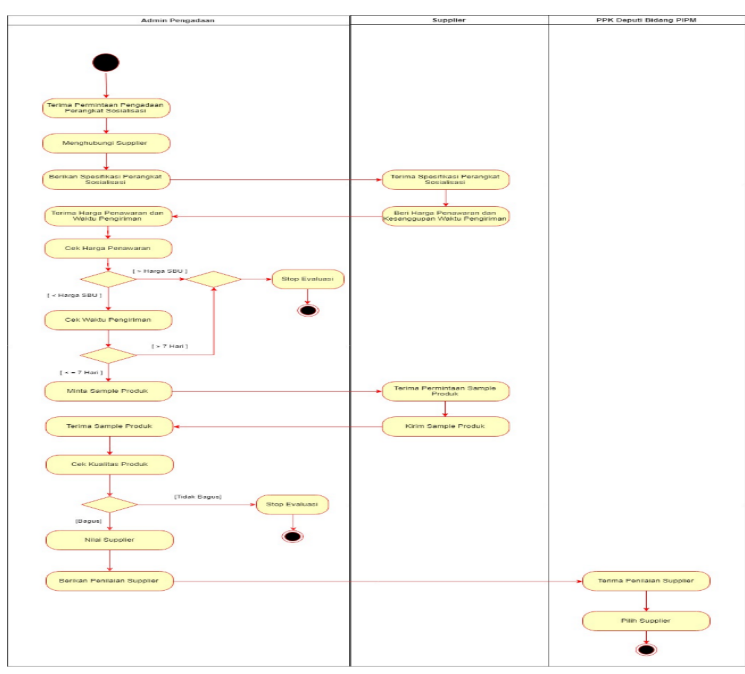

Gambar 2. Activity Diagram Pemilihan Supplier

\subsection{Fishbone Diagram}

Pada Gambar 3, menggambarkan Masalah yang ada didalam penentuan supplier terbaik di Kedeputian Bidang PIPM yaitu pemilihan supplier terbaik belum optimal.

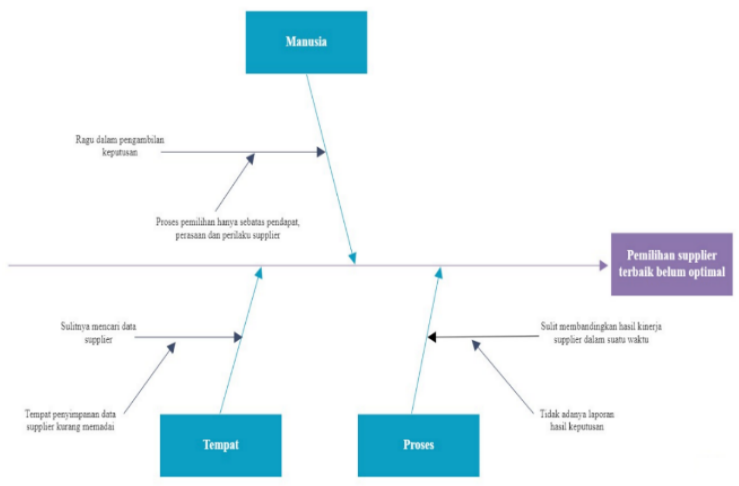

Gambar 3. Fishbone Diagram

\subsection{Pengolahan Data}

a. Kriteria yang dibutuhkan

Berikut ini merupakan kriteria yang dibutuhkan untuk pengambilan keputusan pemilihan supplier terbaik pada Kedeputian Bidang PIPM, sebagaimana tercantum pada Tabel 1.

Tabel 1. Ketentuan Kriteria

\begin{tabular}{lll}
\hline Kode Kriteria & Nama Kriteria & Atribut \\
\hline C01 & Layanan Service & Benefit \\
C02 & Waktu Pengiriman & Cost \\
C03 & Harga & Cost \\
C04 & Kualitas & Benefit \\
\hline
\end{tabular}

b. Bobot Kriteria

Pengambil keputusan yaitu Pejabat Pembuat Komitmen di Kedeputian Bidang PIPM memberikan bobot prioritas pada setiap kriteria sebagaimana tercantum pada Tabel 2 .

Tabel 2. Bobot Kriteria

\begin{tabular}{lll}
\hline Kode Kriteria & Nama Kriteria & Bobot \\
\hline C01 & Layanan Service & $15 \%$ \\
C02 & Waktu Pengiriman & $20 \%$ \\
C03 & Harga & $30 \%$ \\
C04 & Kualitas & $35 \%$ \\
\hline
\end{tabular}

c. Matriks Normalisasi

Implementasi metode Simple Additive Weighting (SAW) dilakukan pada sistem penujang keputusan pemilihan supplier perangkat sosialisasi dengan sejumlah 5 (lima) alternatif supplier, yaitu PT Gita Swarga Loka, PT Satu Imaji, PT Aneka Sakti Bakti, PT Hanfar Solution dan PT Spora Cipta Paramedia. Kelima alternatif supplier tersebut masing-masing memiliki nilai pada kriteria layanan service, waktu pengiriman, harga dan kualitas. Penilaian alternatif supplier dapat dilihat pada Tabel 3.

Tabel 3. Matriks Keputusan X

\begin{tabular}{|c|c|c|c|c|c|}
\hline \multirow[b]{2}{*}{ No } & \multirow{2}{*}{$\begin{array}{c}\text { Alternatif } \\
\text { Supplier }\end{array}$} & \multicolumn{4}{|c|}{ Kriteria } \\
\hline & & $\begin{array}{l}\text { Layanan } \\
\text { Service }\end{array}$ & $\begin{array}{c}\text { Waktu } \\
\text { Pengiriman }\end{array}$ & Harga & Kualitas \\
\hline 1 & $\begin{array}{l}\text { PT. Gita Swarga } \\
\text { Loka }\end{array}$ & 2 & 3 & 4 & 2 \\
\hline 2 & PT. Satu Imaji & 1 & 3 & 4 & 2 \\
\hline 3 & $\begin{array}{l}\text { PT. Aneka Sakti } \\
\text { Bakti }\end{array}$ & 1 & 3 & 3 & 1 \\
\hline 4 & $\begin{array}{l}\text { PT. Hanfar } \\
\text { Solution }\end{array}$ & 2 & 3 & 4 & 1 \\
\hline 5 & $\begin{array}{l}\text { PT. Spora Cipta } \\
\text { Paramedia }\end{array}$ & 1 & 3 & 1 & 1 \\
\hline
\end{tabular}

Setelah matriks keputusan didapatkan, maka langkah selanjutnya adalah melakukan normalisasi dengan persamaan sebagai berikut: 


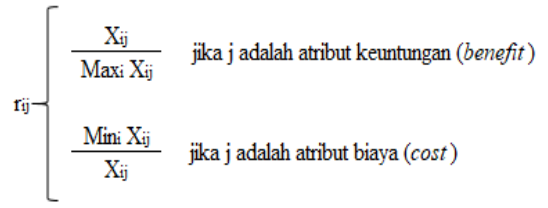

Berikut ini adalah hasil dari perhitungan yang sudah dilakukan pada tiap kriteria sehingga diperoleh nilai dari masing-masing alternatif yang kemudian didapat Matriks Ternormalisasi R sebagaimana tercantum pada Tabel 4.

Tabel 4. Matriks Ternormalisasi R

\begin{tabular}{|c|l|r|r|r|r|}
\hline \multirow{2}{*}{ No } & \multirow{2}{*}{ Alternatif Supplier } & \multicolumn{4}{|c|}{ Kriteria } \\
\cline { 3 - 6 } & $\begin{array}{c}\text { Layanan } \\
\text { Service }\end{array}$ & $\begin{array}{c}\text { Waktu } \\
\text { Pengiriman }\end{array}$ & Harga & Kualitas \\
\hline 1 & $\begin{array}{l}\text { PT. Gita Swarga } \\
\text { Loka }\end{array}$ & 1 & 1 & 0.25 & 1 \\
\hline 2 & PT. Satu Imaji & 0.5 & 1 & 0.25 & 1 \\
\hline 3 & $\begin{array}{l}\text { PT. Aneka Sakti } \\
\text { Bakti }\end{array}$ & 0.5 & 1 & 0.33 & 0.5 \\
\hline 4 & $\begin{array}{l}\text { PT. Hanfar } \\
\text { Solution }\end{array}$ & 1 & 1 & 0.25 & 0.5 \\
\hline 5 & $\begin{array}{l}\text { PT. Spora Cipta } \\
\text { Paramedia }\end{array}$ & 0.5 & 1 & 1 & 0.5 \\
\hline
\end{tabular}

\section{d. Perangkingan Alternatif}

Proses terakhir adalah mencari nilai preferensi $\left(\mathrm{V}_{\mathrm{i}}\right)$ yaitu penjumlahan dari perkalian matriks yang ternormalisasi $\mathrm{R}$ dengan nilai bobot sehingga diperoleh nilai terbesar yang dipilih sebagai alternatif terbaik sebagai solusi.

1) PT Gita Swarga Loka

$=\{(1 \mathrm{x} 0.15)+(1 \mathrm{x} 0.2)+(0.25 \times 0.3)+(1 \times 0.35)\}$

$=(0.15+0.2+0.07+0.35)$

$=0.77$

2) PT Satu Imaji

$=\{(0.5 \times 0.15)+(1 \times 0.2)+(0.25 \times 0.3)+(1 \times 0.35)\}$

$=(0.07+0.2+0.07+0.35)$

$=0.70$

3) PT Aneka Sakti Bakti

$=\{(0.5 \times 0.15)+(1 \times 0.2)+(0.33 \times 0.3)+(0.5 \times 0.35)\}$

$=(0.07+0.2+0.10+0.18)$

$=0.55$

4) PT Hanfar Solution

$=\{(1 \mathrm{x} 0.15)+(1 \mathrm{x} 0.2)+(0.25 \times 0.3)+(0.5 \times 0.35)\}$

$=(0.15+0.2+0.07+0.18)$

$=0.60$

5) PT Spora Cipta Paramedia

$=\{(0.5 \times 0.15)+(1 \times 0.2)+(1 \times 0.3)+(0.5 \times 0.35)\}$

$=(0.07+0.2+0.3+0.18)$

$=0.75$

e. Hasil Penelitian

Nilai akhir alternatif supplier pada Tabel 5 adalah hasil perhitungan akhir setiap alternatif supplier dengan perhitungan manual. Calon supplier yang memiliki nilai akhir terbesar adalah yang direkomendasikan sebagai supplier terbaik. Dari hasil peringkat masing-masing supplier terlihat bahwa supplier yang direkomendasikan adalah PT Gita Swarga Loka dengan perolehan nilai 0.77.

Tabel 5. Hasil Perangkingan Supplier

\begin{tabular}{|c|l|r|r|r|r|r|}
\hline No & \multicolumn{1}{|c|}{$\begin{array}{c}\text { Alternatif } \\
\text { Supplier }\end{array}$} & $\begin{array}{c}\text { Layanan } \\
\text { Service }\end{array}$ & $\begin{array}{c}\text { Kriteria } \\
\text { Pengiriman }\end{array}$ & Harga & Kualitas & $\begin{array}{c}\text { Nilai } \\
\text { Akhir }\end{array}$ \\
\hline 1 & $\begin{array}{l}\text { PT. Gita } \\
\text { Swarga Loka }\end{array}$ & 0.15 & 0.2 & 0.07 & 0.35 & $\mathbf{0 . 7 7}$ \\
\hline & $\begin{array}{l}\text { PT. Spora } \\
\text { Cipta } \\
\text { Paramedia }\end{array}$ & 0.07 & 0.2 & 0.3 & 0.18 & $\mathbf{0 . 7 5}$ \\
\hline 3 & $\begin{array}{l}\text { PT. Satu } \\
\text { Imaji }\end{array}$ & 0.07 & 0.2 & 0.07 & 0.35 & $\mathbf{0 . 7 0}$ \\
\hline 4 & $\begin{array}{l}\text { PT. Hanfar } \\
\text { Solution }\end{array}$ & 0.15 & 0.2 & 0.07 & 0.18 & $\mathbf{0 . 6 0}$ \\
\hline 5 & $\begin{array}{l}\text { PT. Aneka } \\
\text { Sakti Bakti }\end{array}$ & 0.07 & 0.2 & 0.10 & 0.18 & $\mathbf{0 . 5 5}$ \\
\hline
\end{tabular}

\subsection{Use Case Diagram}

a. Use Case Diagram Input

Use case diagram input terdiri dari entry data supplier, entry data kriteria, dan entry data subkriteria yang disajikan pada Gambar 4.

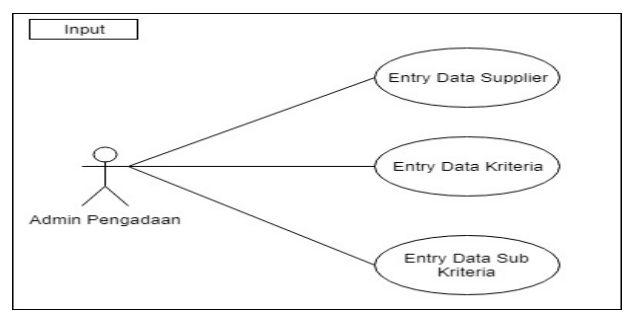

Gambar 4. Use Case Diagram Input

b. Use Case Diagram Proses

Use case diagram proses terdiri dari entry nilai supplier, hitung nilai supplier, entry pemilihan supplier dan cetak surat keputusan yang disajikan pada Gambar 5.

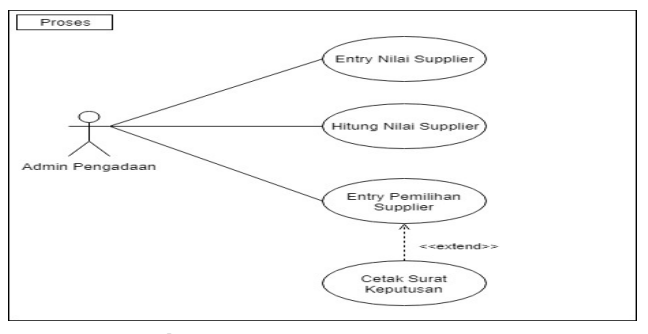

Gambar 5. Use Case Diagram Proses

c. Use Case Diagram Laporan

Use case diagram laporan terdiri dari cetak laporan penilaian supplier, dan cetak laporan perangkingan supplier yang disajikan pada Gambar 6. 


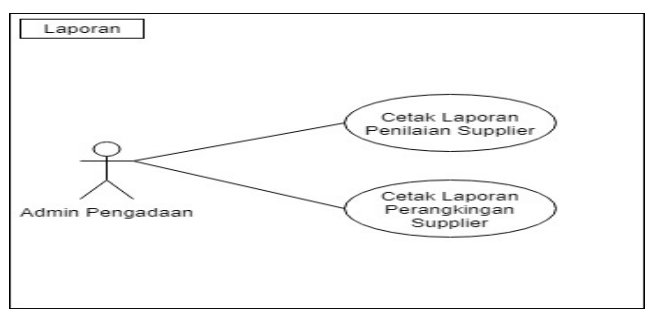

Gambar 6. Use Case Diagram Laporan

\subsection{Class Diagram}

Berdasarkan hasil analisis data yang sudah dilakukan sebelumnya, berikut adalah database yang digunakan pada sistem penunjang keputusan pemilihan supplier pada Kedeputian Bidang PIPM sebagaimana disajikan pada Gambar 7. Ada 6 tabel yang digunakan yaitu: supplier, kriteria, subkriteria, nilai_supplier, penilaian dan surat_keputusan.

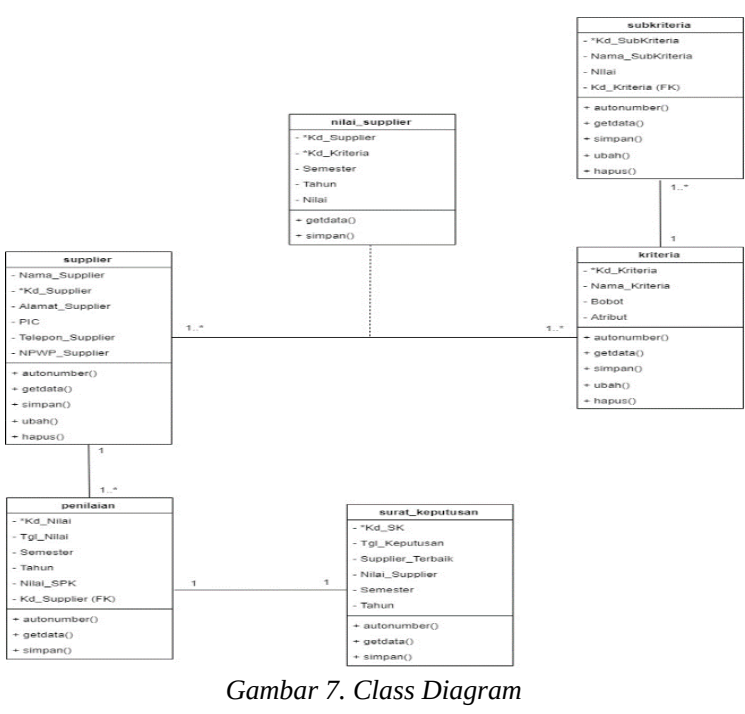

\subsection{Implementasi SPK}

\section{a. Form Menu Utama}

Saat pertama sistem dijalankan, maka akan muncul form menu utama yang disajikan pada Gambar 9. Terdapat tiga menu yaitu input, proses dan laporan, dimana masing-masing menu mempunyai sub-menu. Menu input data mempunyai sub-menu form entry data supplier, form entry data kriteria dan form entry data subkriteria. Kemudian menu proses data mempunyai sub-menu form entry nilai supplier, form hitung nilai supplier dan form entry pemilihan supplier, sedangkan menu laporan mempunyai sub-menu cetak laporan penilaian supplier, dan cetak laporan perangkingan supplier.

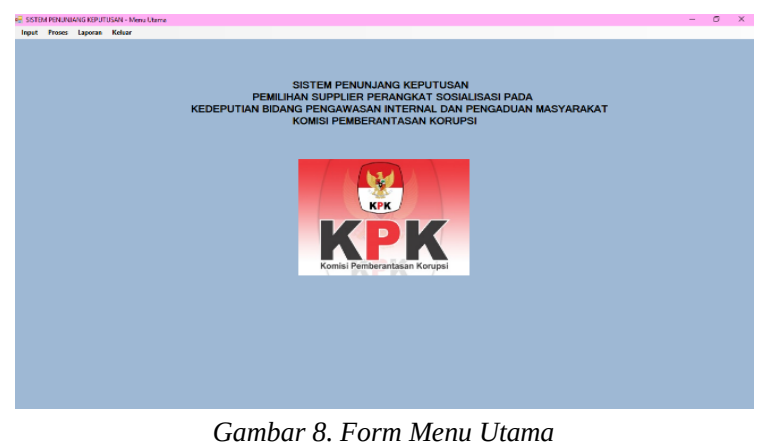

b. Form Entry Nilai Supplier

Form entry nilai supplier yang disajikan pada Gambar 13 terdapat pada menubar Proses. Form ini digunakan untuk meng-input nilai supplier per kriteria dalam proses pengambilan keputusan.

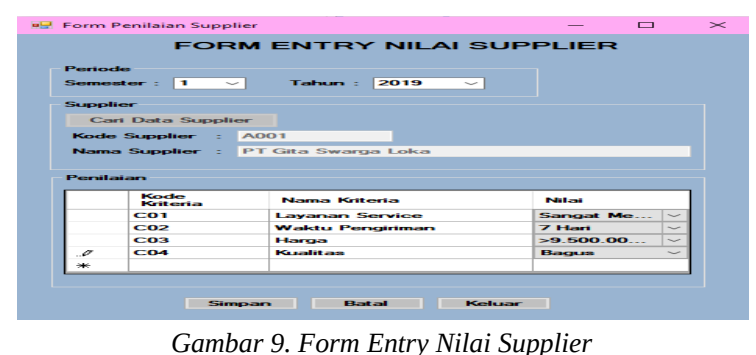

c. Form Hitung Nilai Supplier

Form hitung nilai supplier terdapat pada menubar Proses. Form hitung nilai supplier terdiri dari 2 (dua) tab yaitu tab data nilai supplier dan tab proses penilaian.

Pada Gambar 14, menampilkan Form Tab data nilai supplier. Form ini digunakan untuk menampilkan data nilai supplier yang sebelumnya telah di input pada form entry nilai supplier.

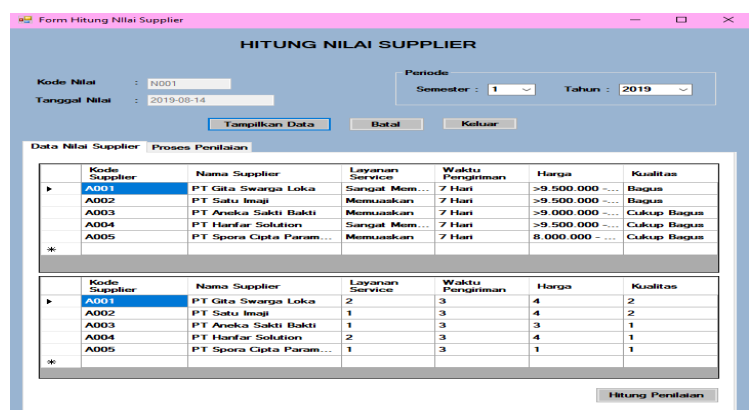

Gambar 10. Form Tab Data Nilai Supplier

Pada Gambar 15, menampilkan Form Tab proses penilaian. Form ini digunakan untuk menampilkan hasil perhitungan normalisasi dan perangkingan supplier menggunakan metode Simple Additive Weighting (SAW). 


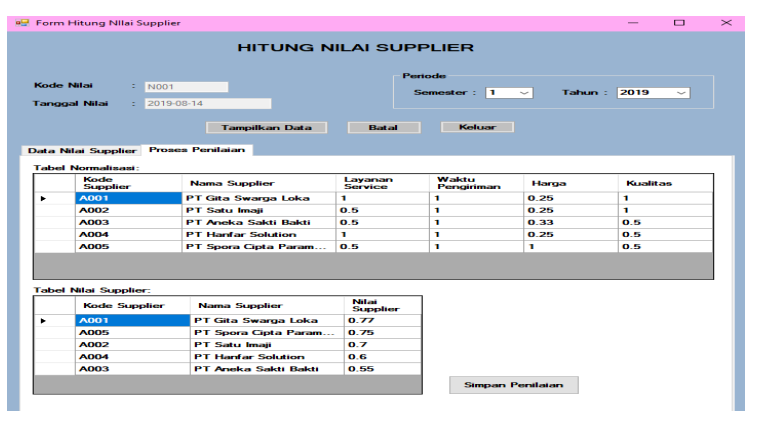

Gambar 11. Form Tab Proses Penilaian

d. Form Entry Pemilihan Supplier

Pada Gambar 16, menampilkan form entry pemilihan supplier. Form ini digunakan untuk menentukan supplier yang akan dipilih menjadi supplier terbaik untuk pengadaan perangkat sosialisasi pada Kedeputian Bidang PIPM.

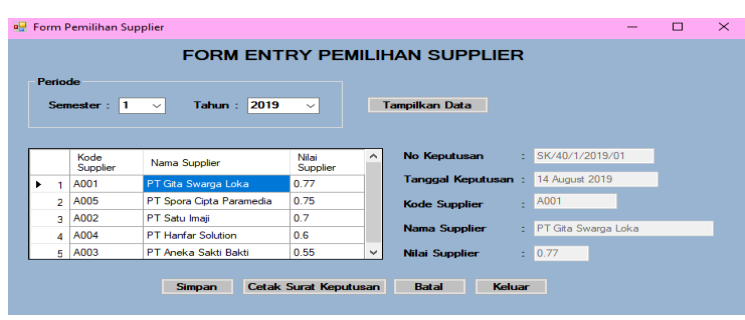

Gambar 12. Form Entry Pemilihan Supplier

\section{KESIMPULAN}

Berdasarkan analisa yang telah dilakukan, dapat disimpulkan beberapa hal sebagai berikut:

a. Dengan adanya Sistem Penunjang Keputusan ini dapat membantu Pejabat Pembuat Komitmen di Kedeputian Bidang PIPM dalam menentukan supplier terbaik.

b. Sistem pemilihan supplier dengan menerapkan metode perhitungan Simple Additive Weighting (SAW) mempercepat proses seleksi pemilihan supplier terbaik, dan mengurangi kesalahan pada saat menentukannya.

c. Dengan menggunakan metode Simple Additive Weighting (SAW) dapat menghasilkan rekomendasi-rekomendasi supplier secara tepat dan cepat pada Kedeputian Bidang PIPM.

d. Berdasarkan hasil perhitungan menggunakan metode Simple Additive Weighting (SAW), secara keseluruhan PT. Gita Swarga Loka dinilai sebagai supplier terbaik dengan nilai akhir yang diperoleh sebesar (0.77). Kemudian diikuti oleh supplier lainnya yaitu PT. Spora Cipta paramedia memperoleh nilai akhir sebesar (0.75), PT Satu Imaji memperoleh nilai akhir sebesar (0.7), PT Hanfar Solution memperoleh nilai akhir sebesar (0.6), dan yang terakhir adalah PT. Aneka Sakti Bakti dengan perolehan nilai akhir sebesar (0.55).

\section{DAFTAR PUSTAKA}

[1] Sutabri, Tata. Konsep Sistem Informasi. Yogyakarta: Andi. 2012.

[2] Vercellis, Carlo. Business Intelligence: Data Mining and Optimization for Decision Making. United Kingdom: John Wiley \& Sons. 2009.

[3] Kusumadewi, Sri, S Hartati, A Harjoko, and R Wardoyo. Fuzzy Multi-Attribute Decision Making (FUZZY MADM). Yogyakarta: Graha Ilmu. 2006.

[4] Pradipta, and Diana. "Sistem Penunjang Keputusan Supplier Pada Apotek Dengan Metode AHP Dan SAW (Studi Kasus Apotek XYZ).” Universitas Budi Luhur Jakarta. 2017.

[5] Nardiono. "B. Komparasi Metode Simple Additive Weighting (SAW) Dan Metode Weighted Product (WP) Dalam Menentukan Karyawan Terbaik (Studi Kasus: PT. Matrixnet Global Indonesia.” Universitas Pamulang. 2017. 